\title{
Article
}

\section{Sketching women in court: The visual construction of co-accused women in court drawings}

Barlow, Charlotte

Available at http://clok.uclan.ac.uk/39818/

Barlow, Charlotte ORCID: 0000-0002-1362-7131 (2016) Sketching women in court: The visual construction of co-accused women in court drawings.

Feminist Legal Studies, 24 . pp. 169-192. ISSN 0966-3622

It is advisable to refer to the publisher's version if you intend to cite from the work. http://dx.doi.org/10.1007/s10691-016-9310-3

For more information about UCLan's research in this area go to http://www.uclan.ac.uk/researchgroups/ and search for < name of research Group>.

For information about Research generally at UCLan please go to http://www.uclan.ac.uk/research/

All outputs in CLoK are protected by Intellectual Property Rights law, including Copyright law. Copyright, IPR and Moral Rights for the works on this site are retained by the individual authors and/or other copyright owners. Terms and conditions for use of this material are defined in the policies page.

\section{CLoK}

Central Lancashire online Knowledge www.clok.uclan.ac.uk

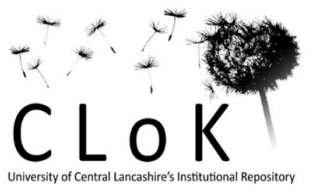


Sketching women in court: The visual construction of co-accused women in court

\title{
drawings
}

\begin{abstract}
This paper explores the visual construction and representation of co-accused women offenders in court drawings. It utilises three case studies of female co-defendants who appeared in the England and Wales court system between 2003 and 2013. In doing so this paper falls into three parts. The first part considers the emergence of the subdiscipline, visual criminology and examines what is known about the visual representation of female offenders. The second part presents the findings of an empirical investigation, which involved engaging in a critical, reflexive visual analysis of a selection of court drawings of three female co-offenders. The third part discusses the ways in which issues such as the court artist's subjectivity and dominant, simplistic, motifs of female offenders served to reinforce existing myths and prejudices which typically characterise the representation of such women.
\end{abstract}




\section{Introduction}

Within criminology there has traditionally been a preoccupation with objectivity, statistical analysis and the written narrative, which Young (2011) refers to as the 'bogus of positivism'. However, in recent years, there has been a growing recognition of the significance and 'spectacle' of the image, emphasising the cultural, social and political power of images of legal, crime and criminal justice issues (see, for example, Rafter, 2014; Ferrell et al, 2004; Hayward \& Presdee, 2010; Carrabine, 2014). Much of this literature discusses the use of photography, particularly focussing on issues such as witnessing trauma (Walklate et al, 2011), images of violence (Carrabine, 2014) and the 'mug-shot' (Birch, 1993; Finn, 2009). However, there is little discussion of the visual construction of court drawings, particularly from a feminist perspective.

This paper will explore the visual construction and representation of a selection of UK court drawings from three case studies of female co-offenders. It will critically consider how court drawings may represent the cultural and social processes that underpin the construction and public understanding of female offenders in court. Consequently, this paper not only seeks to deconstruct the court drawings of the female co-offenders, but to also use the images as an introduction to a discussion about the over-simplistic, partial and androcentric construction of women in court. 
The court drawings analysed in this paper are taken from three UK case studies of coaccused women, all of whom co-offended with a male partner, namely Vanessa George, Maxine Carr and Vicky Pryce. These three cases were selected given that they were recent and high profile examples of female co-offending and the crimes that they were convicted of ranged in seriousness. Vanessa George was a nursery worker, who was involved in the exchange of indecent imagery of children via an online paedophile ring. She was eventually convicted and sentenced in 2009. Maxine Carr was convicted for perverting the course of justice in the Holly Wells and Jessica Chapman murder case in 2003. Her then partner, Ian Huntley, was charged with the murder of the two schoolchildren and Maxine Carr provided a false alibi for him on the night of their murder (Gerrard, 2004). Finally, Vicky Pryce was convicted of perverting the course of justice in 2012 for knowingly taking her then husband, Chris Huhne’s, speeding penalty points in 2003. This transpired as Pryce disclosed to the British press in 2011 that Huhne had forced an unnamed individual to take his speeding penalty points. This incident, coincidently or not, followed a public divorce between the couple following Huhne's disclosure of an affair. Despite aiming to remain anonymous, it eventually emerged that it was Pryce who had taken the penalty points on her husband's behalf. This case would ordinarily not capture the public's attention, however, Chris Huhne's (previous) status as a Liberal Democrat MP and Vicky Pryce’s position as a leading UK economist arguably increased the newsworthiness and profile of this case. 
The twelve court drawings were analysed using a critical reflective method and whilst the co-defendants, particularly the women, were the primary focus, the whole image was analysed to explore the broader representation and construction of court drawings. Before discussing the analysis of the visual representation of the three aforementioned female co-offenders in court drawings, the paper will provide an overview of the existing, related literature, discussing visual criminology and the visual representation of female offenders.

\section{Visual Criminology and 'Images' of Crime}

Images of crime are arguably becoming as real as crime and criminal justice itself (Hayward and Presdee, 2010). According to Greer et al (2007: 5), "the visual constitutes perhaps the central medium through which the meanings and emotions of crime are captured and conveyed to audiences”. It is arguably the visual that increasingly shapes our engagement with and understanding of key issues related to crime and crime control (Greer et al, 2007; Hayward and Presdee, 2010; Rafter, 2014). Power is increasingly exercised through mediated representation and symbolic production, therefore the image and cultural representation emerge as key components of negotiating late modern reality (Ferrell, Hayward and Young, 2008; Hayward and Presdee, 2010). 
Ferrell et al (2008) argue that it is difficult to imagine how criminology could not be regarded as 'visual', particularly in an age where images of crime are continually thrust into public consciousness through a variety of media sources. Due to this increasing recognition of the significance of the visual, there has been a recent emergence of the sub-discipline ‘visual criminology’. According to Rafter (2014: 129), “visual criminology is the study of the ways in which all things visual interact with crime and criminal justice, inventing and shaping one another”. Visual criminology engages with the meaning, affect, symbolic power and spectacle of the 'image', thus encouraging a critical engagement with and expansion of the criminological imagination (Hayward, \& Presdee, 2010; Young, 2011). To fully engage with a visual criminological approach, visual analysis must be attuned to representation as well as the ways in which visual culture impacts upon individual and collective behaviour (Hayward, 2010).

To date, much of the work of visual criminology has focussed on the use of photographs (Carrabine, 2014; 2012; Walklate et al, 2011) and video or television (Brown and Rafter, 2013). The birth of the camera intersects with criminology in many ways, such as the traditional police photograph or 'mug shot' (Carrabine, 2014) or less obvious examples, such as the fingerprint (Finn, 2009). Photographs are often understood as being a more objective form of representation, particularly in comparison to drawings or sketches, hence why they are often used in law enforcement and criminal identification (Finn, 2009; Marder, 2013). However, irrespective of the ability of the photograph to capture a 'moment in time' and the consequential belief that this leads to 
an objective 'truth', the subjective influence of the photographer on the end result has increasingly been acknowledged (Finn, 2009). Sekula (1981) challenged approaches to photography that ignored the social and political functions of images and exposed their ideological interplay in wider systems of classification, control and order. Furthermore, Ferrell and van de Voorde (2010: 41) argue that a photograph captures "not that of the people in front of the lens, nor that of the photographer, but of the shared cultural meaning created between the photographer and those photographed in a particular context”. This highlights that the power of photographs lies in both their ability to display life events and on their conative ability to draw upon broad symbolic systems, visually representing hidden codes of meaning (Barthes, 1977).

Particularly significant to this paper are the links between the physical image and criminality primarily discussed in Lombroso's work on the 'born criminal' and female criminality. Lombroso (1876) made direct links between the physical body and criminal propensity and by extension, captured this in its visual representation by deploying the 'mugshot' as a key document in his work. Lombroso utilised images of 'born criminals' in much of his work and also established a museum of criminal anthropology (Rafter, 2014). As highlighted by Rafter (2014: 130), “no criminologist has ever drawn more heavily on the visual, or revelled more in the imagery of crime”. Similarly in a UK context, the statistician, Galton (1879), used composite photographs of convicts to identify a biologically determined 'average' offender. With this in mind, the intersection of crime and photography during this time period implied that certain types of body are 
more prone to deviancy and thus visibly identifiable as 'criminal'. The use of photography and visual imagery within law enforcement practices reflect socially constructed categories of what constitutes criminality. As argued by Finn (2009: 30), "the criminal body was defined in terms that reflected racial and gender biases and that supported existing social theories and hierarchies”. This exercise of power through law enforcement techniques reinforced the normalcy of the white, male body and consequently stigmatised other bodies as anomalous and therefore deviant (Finn, 2009). Despite Lombroso and Ferrero’s (1893) work being published during the Victorian period, it provides a useful insight into the myths and prejudices that remain to have a significant impact on the study of women and crime today, primarily in terms of dominant images of female offending (Lloyd, 1995).

However, although the last couple of decades has witnessed an increased interest in the 'visual' in criminology and the social sciences more broadly, drawing has all but been neglected from this process (For example Rose, 2007; Pink, 2006). A notable exception is the plethora of work exploring graffiti art and crime (For example, Glazer, 1979; Austin, 2001; Snyder, 2009), but other types of drawing have received much less critical consideration within criminology. Within the social sciences, the use of drawings is often discussed in relation to how this method can benefit or support children during difficult situations, such as investigative interviewing (Poole \& Dickinson, 2014; Katz et al, 2014) and discussing experiences of bullying (Andreou, Bonoti, 2010). However, in spite of this absence in criminology, art history is gradually 
exploring the complex relationship between law and art, particularly in relation to photography and increasingly courtroom sketches (Young, 2005)

Photography and sketching in court and the publication of such photographs or sketches have been prohibited in English law since 1925 (Nead, 2005; Cheston, 2010). Court artists are consequently unable to sketch whilst in court and are thus expected to memorise colours, clothing, facial mannerisms and physical idiosyncrasies of those involved in a particular court case (Cheston, 2010). The production of court drawings is therefore based on 'objective' evidence, yet is a subjective testimony of a particular day, moment or incident in court. Nead (2005: 182) argues that:

"We are present at the trial only by virtue of the courtroom sketch; but the sketch does not have the unmediated presence of the camera. We are aware of its artifice and of the agency of the artist; we are conscious of the act of portrayal”.

Furthermore, court artists are often required to compress hours of court action into a single drawing that crystalizes events, thus highlighting the subjective and partial nature of this type of image. Court drawings are often intended to illustrate news reports, therefore the style of the drawing and the included and excluded detail is likely to be influenced by imagining the intended audience for the work (Nead, 2005). As highlighted by Surette (1998), media and legal systems should not be viewed as being 
autonomous entities, rather the complex interactions and relationship between them should be closely examined. While the use of court drawings in news reports will not be analysed in this paper, the context and purpose of production will be critically considered.

Arguably, there may come a time when court artistry is no longer needed in the UK, as cameras are now allowed in Scottish courtrooms and cameras were used in the England and Wales Court of Appeal for the first time in England in October 2013. However, court artistry currently remains to be the general publics’ main, if not only, visual insight into what happens in court, therefore the artistic impression is a vital source of information regarding legal and criminal justice issues.

\section{Gender, Crime and the Visual}

Before critically considering the intersection of gender, crime and the visual, it is important to reflect on how female offenders are constructed and understood more broadly. As highlighted by Lloyd (1995), female offenders are ‘doubly deviant, doubly damned' as they are not only judged for transgressing the criminal law, but more importantly, the laws governing acceptable forms of femininity. Consequently, the criminal woman is judged both for the crime that she has committed, but also for the 
sort of woman that she is (Lloyd, 1995). Edwards (1984) argues that this notion can influence women's position and construction in court, as she suggests that women are on trial for both their criminality, but also the extent to which they are perceived to be feminine and a good wife and mother. Women are judged against the 'reasonable man' of the law, therefore not only does this invoke the experiences and values of men upon women, (Naffine, 1987), but it also means that women are easily placed into 'manmade’ dichotomies in an attempt to explain their behaviour (Ballinger, 2012).

Consequently, representations of female offenders often become entrenched with over-simplistic categories such as, 'mythical monsters', 'bad mother' or 'mad' or 'bad' (Ballinger, 2000; Jewkes, 2015; Jones and Wardle, 2008). Those women who fall into the 'mad' category are often portrayed as being unstable or hysterical, whereas those who are constructed as bad are viewed to be inherently evil and wilfully defiant of their gender role expectations (Berrington et al, 2002; Heidensohn, 1996; Lloyd, 1995). Such over-simplistic, dichotomous and deterministic frames of reference for female offending impacts upon the ways in which such behaviour is constructed and understood, despite the reality of such women’s lives being much more complex (Ballinger, 2000; 2012). In summary, in an effort to make criminal women’s actions appear less of a concern to society, female offending is often individualised, pathologised and explained by over-simplistic and deterministic explanations such as being inherently evil or psychologically impaired (Myers and Wight, 1996; Naylor, 2001; Barnett, 2006). 
Despite the fact that women historically and contemporaneously commit less crime than men (Heidensohn, 1996; Wykes, 1998), Heidensohn (2002) argues that women criminals provide some of the most compelling images of crime and deviancy. Crime is generally constructed as a masculine act (Naffine, 1987; Ballinger, 2000; Jewkes, 2015), therefore men's offending is normalised to a greater extent than women's criminality. Feminist criminologists have argued that the law and legal institutions are defined by gendered discourses (Smart, 1977; Carlen, 2002; Ballinger, 2000; 2007; 2012). Ballinger (2012), for example, argues that women are limited to subject positions in court and the gendered nature of the law and the pervasive male hierarchy of knowledge has particularly negative consequences for female offenders who stand trial. Consequently, female criminals who commit typically 'unfeminine' offences, such as violent acts, crimes against children or murder, are treated and represented harshly (Grabe et al, 2006; Ballinger, 2000)

Despite the growing body of literature, which explores the legal and media representation of female offenders more broadly (For example, Ballinger, 2012; Edwards, 1984; Jewkes, 2015; Barnett, 2006; Naylor, 2001; Grabe et al, 2006), there has been little research which explicitly explores the visual representation of women criminals, with some notable exceptions. Birch (1993), argued that due to the media's 
distinct and purposeful use of imagery during the reporting of Myra Hindley ${ }^{1}$, particularly the use of the now infamous mugshot, the image of her dyed blonde hair and impassive stare, connotes "modern affectless evil in a way that the contemporary photograph of Brady never has” (French, 1996: 38). In addition, Jones and Wardle (2008) explored the visual construction of Maxine Carr and demonstrated the 'power' that images in news can have on representation. Jones and Wardle (2008: 68) argue that the use and placement of images in the media representation of Maxine Carr led to a "total annihilation” of her character and consequently implied that she was 'equally guilty' and an 'equal partner' to Ian Huntley, in spite of her secondary role in the offending. Furthermore Yardley and Wilson (2015) argue that the images and drawings of Mary Ann Cotton ${ }^{2}$ were deliberately coarsened to make her appear less attractive, arguably to distance her crimes from idealised versions of femininity and womanhood.

However, much of the existing literature within this area locates the visual analysis of female offenders within a media representation context and considers the use of images in relation to their placement, in page layouts and against the wider written narrative of the women's representation. An exception to this is Mulcahy (2015b), who analysed the mugshots of suffragettes who refused to have their photograph voluntarily taken on admission to prison. She argued that unlike other women offenders portrayed in

\footnotetext{
${ }^{1}$ Myra Hindley was convicted with her partner, Ian Brady, of murdering five children between 1963-65. She was sentenced in 1966 to life imprisonment and she later died in prison in 2002.

${ }^{2}$ Mary Ann Cotton was convicted and hanged for poisoning and subsequently murdering up to 21 victims in the late 1800's
} 
photographic archives of the police, the suffragette's had the resources and inclination to challenge how they were represented and what it meant to be labelled criminal. However, to date, there has been little exploration of the visual construction of women offenders within a legal context and a distinct absence of their representation in court drawings. With this in mind, this paper applies a critical and reflexive approach to the visual construction of female offenders in court drawings. This challenges the 'bogus of positivism' associated with criminology, which privileges the written text over the spectacle of the image (Young, 2011; Pink, 2007; Hayward and Presdee, 2010) and also attempts to progress visual criminology's engagement with representation beyond the scope of the photograph.

\section{Critical Visual Methodological Approach}

While images should not necessarily replace words as the dominant mode of research, they should be regarded as equally meaningful (Pink, 2007; Rafter, 2014). Cunneen (2010: 133) suggests that an analysis of images provides the opportunity to "break out of the positivist epistemological straight jacket” that has dominated criminological theory and practice. Pink (2007) argues that visual analysis should be conducted reflexively and outlines three key principles of visual analysis. Firstly, Pink (2007) argues that it is impossible to gain an objective and 'true' visual record of any 
process. Secondly, she suggests that the context of image production should be analysed to consider how visual content is informed by subjectivities. Finally, analysis should focus on the content of images, as well as the meanings that different individuals give to those images in different contexts (Pink, 2007). A method of analysis based loosely on Pink’s (2007) suggestions is adopted in this paper. This analytical approach is purposefully reflexive and aims to deconstruct the image, as well as use the image as an entrée into a discussion about the often over-simplistic and gendered construction of female co-offenders in court.

Furthermore, Barthes (1977) argues that photographs are loaded messages packed with encoded cultural meanings that are not apparent at first glance. This paper applies this concept to court drawings and explores both the denotative (literal) level of the drawings as well as the connotative (figurative). This approach considers the ways in which ideology informs discursive meanings to purport and transmit 'truths' and 'realities' about co-accused women in court.

The visual analysis adopts a feminist approach, particularly drawing on the work of Smart (1989). Following and extending Foucault, Smart (1989) argues that law is a powerful discourse, which has exclusionary and damaging effects for women. Combining Pink’s (2007) approach to visual analysis, with aspects of Smart’s (1989) feminist critique of law, enables a critical understanding of the ways in which the court drawings reinforce and perpetuate the gendered nature of law, which thus disqualifies the experience and knowledge of women subjects (Smart, 1989). 
It is recognised that the meaning of the court drawings are overlaid by the author's own, personal interpretations and the endeavours of this paper are admittedly subjective (Walklate et al, 2011). Nonetheless, the reflexive and critical approach to analysis enables an exploration as to what the images imply about the wider world, rather than solely considering what they mean in and of themselves. As highlighted by Pink (2007: 118-119), analysis is not simply a matter of interpreting the visual content of images, but also involves "examining how different producers and viewers of images give subjective meanings to their content and form”. Thus this paper aims to establish what we 'see' of a particular moment in court and what we do not 'see' (Walklate, McGarry and Mythen, 2014). It is also important to note that at the time of writing, there are three court artists in the UK, all of whom are women and the potential significance of this will be discussed later in the paper. With all of this in mind, this paper seeks to critically consider how court drawings may represent the cultural and social processes that underpin the construction and public understanding of women criminals in court.

The three cases chosen in this paper were selected due to them being high-profile examples of female co-offending, each case having a selection of court drawings to analyse and the offences committed ranging in seriousness, thus allowing the opportunity for comparison. Although the court drawings were analysed on a case by case, image by image basis, a number of key themes have been identified across each of the three case studies. Consequently, the findings section has been structured around these themes. The trials occurred between 2003 and 2013 and there were 15 publically 
accessible court drawings available for analysis (three for Vanessa George, seven for Maxine Carr and six for Vicky Pryce). It was ensured that all of the court drawings publically available were obtained for analysis by accessing them via the court artist directly, or via their website. The images that were not selected were mostly cropped versions of the drawings already selected for analysis. Due to the analysis focussing on the full drawing, rather than the context in which it was used in media, it was concluded that the cropped versions would not add to the analysis. When analysing the images, whilst the co-defendants, particularly the women, were the primary focus, the whole image was analysed to explore the broader representation and construction of court drawings.

It is also significant to note that I attended the trial of Vicky Pryce and Chris Huhne, which is one of the case studies analysed and although this is not considered to be a formal research method in the context of this study, it is viewed as being a semiethnographic aspect of the research. I attended the full trial and kept a reflective diary throughout the process. This experience enabled a critical consideration as to which aspects of this particular case were included, excluded and emphasized in the court drawings analysed. It is recognized that my analysis of Pryce’s drawings are to some extent qualitatively different to Carr and George, as I was able to draw comparisons to my experience of being in court during the trial. However, the main analytical technique utilized in this paper is a visual analysis of the court drawings themselves and my 
experience of witnessing the Pryce trial is used as a comparative tool, rather than an analytical technique in and of itself, as and when appropriate for this particular case.

\section{Findings: The Court Room as 'Male Space'.}

A key observation of each of the court drawings was the evident maleness and masculinity of the courtroom. In the Vicky Pryce drawings in particular, she was often the only woman in the image and if other women were present, they were in the background or periphery of the sketch. For example, in Figure 1 which represents Pryce's first day in court, whilst there are other women present in this image, they are voyeurs (i.e. spectators/ onlookers) of the trial and are thus constructed as being nonactive members of the courtroom. (INSERT FIGURE 1 HERE).

This reinforces the dominant construction of women being passive and lacking the authority of knowledge, which is particularly evident in typically male environments such as the courtroom (Sydie, 1987; Russett, 1989; Bondi, 1997). This observation is significant, as from my experience of witnessing the trial, there were two women court clerks involved in the case, yet in this particular image, all of the legal representatives are male. As outlined in Pink's (2007) approach to visual analysis, this highlights the impossibility of gaining a true visual record of a particular moment or process. 
Furthermore, this suggests that the subjectivities of the court artist and the typically masculine nature of the courtroom led to the drawing to some extent contradicting the reality of the trial, thus reinforcing the male-defined nature of the legal process (Ballinger, 2012).

Significantly, in each of the images analysed, none of the women are drawn as actively speaking, but rather they are passively listening. For example, in Figure 2it is Pryce's male co-defendant, Chris Huhne, who is drawn as being the active voice. The angles of the image reinforce the man as active, woman as passive dichotomy, as Huhne is standing up and drawn as being on the same level as the male judge, whereas the two women (Pryce and the female legal representative) are lower and sitting down, thus visually reinforcing the gendered power imbalance. (INSERT FIGURE 2 HERE). This is also evident in Figure 9 as Ian Huntley, Carr's male co-defendant, is actively speaking and being listened to/ observed by court and legal representatives. In contrast Carr is passively listening, due to her body language implying that she is leaning in, thus visually constructing her as a passive voyeur of the trial (INSERT FIGURE 9 HERE).

Although Huntley's status as an active participant is unsurprising here, as this drawing represents Huntley giving evidence in court, there were no court drawings of Carr giving evidence available for analysis, despite her testimony lasting for two days. 
Furthermore, other drawings of Carr and Huntley also echo this passive/ active binary, such as Figure 10 (INSERT FIGURE 10 HERE).

The context of the image production (Pink, 2007) and the potential influence of the court artist's subjectivities is particularly significant to this analysis, as this collectively suggests that the drawings of the women served to reinforce the association of women being 'passive' knowers in comparison to their 'active' male counterparts (Russett, 1989). Women’s voices and perspectives, by their very nature, are viewed to be less significant, important and knowledgeable than men’s (Beard, 2014; Russett, 1989; Smart, 1989). This legal and public domination of the male perspective has led to all experiences and behaviour which falls outside these parameters to be 'othered' and not granted epistemic privilege (Barlow, 2015; Ballinger, 2012; Carline, 2005). Ballinger (2012: 452) argues that such principles lead to a double exclusion of the female experience, due to both the gendered nature of the law and male knowledge being viewed to be hierarchically more valuable.

Pink (2007) suggests that analysis should focus on content as well as the meanings individuals give to images in different contexts. If the aforementioned images were considered in isolation, viewers of the images may perceive that the women being portrayed as passive was indicative of this particular day in court. However, when analysed together, it is evident that a lack of authority and autonomy of the women is a common feature of women co-offenders in court drawings, which consequently excludes and denies their experiences and perspectives (Smart, 1989). With this in 
mind, the lack of authority of the women in the court sketches, particularly in comparison to their male counterparts, serves two purposes. Firstly, this emphasized the notion of the courtroom being a male- defined space where women, due to their very nature, are 'othered'. Consequently, this serves to reinforce the incomprehensibility of a woman being on trial, thus emphasizing the 'doubly deviant' nature of female offenders more broadly.

\section{Spectators, Voyeurs and Women as 'Other'}

This notion of 'othering' was also manifest more directly in a number of the court drawings analysed due to the emphasis on the 'spectacle' of the women being on trial. Constructing individuals or groups as 'others' marks the normative boundaries of society, where the 'other' is mostly excluded serving to create distinct boundaries between 'us' and 'them' (Riggins, 1997; Young, 1999). Within the context of crime and deviance, it has been argued that 'othering' stems from societal insecurity in late modernity, as creating 'others' is a direct response to a more diverse social order (Young, 1999).

In Figure 1 there is a significant presence of other individuals in the drawing, including the Judge, jurors and spectators, who are a contrast to Vicky Pryce, alone at 
the centre of the image in what is arguably constructed to be a 'display' box. It is argued in this paper that the visual construction of this drawing serves two functions. Firstly, the notion of Pryce being 'on show' for all to see at the centre of the image has 'monster' connotations. Although Pryce was placed in a windowed area in court after being escorted from her police cell, both Huhne (her male co-offender) and a police officer were also present with her at this point in the trial. The exaggerated isolation of the glass box therefore gives the distinct impression that she is 'caged', thus emphasising her status as 'other'. Secondly, it is acknowledged here that different viewers of this image will give differing subjective meanings to its content and form (Pink, 2007). For instance, the aforementioned 'monstrous' connotations of Figure 1 may rather be interpreted as the busy nature of the courtroom during this particular day in court. However, this drawing somewhat contradicts my experience of being in court, as whilst the courtroom was undoubtedly busy, it was not 'full to capacity', as this image implies. This contradiction thus serves to reinforce and exaggerate the 'spectacle' of the trial. In addition, when comparing this to the court drawings of Huhne, he is usually drawn either alone (see figure 11) or with a small number of other individuals in the image (usually Vicky Pryce and the Judge), therefore the 'spectacle’ of him being on trial is minimised. This serves to emphasise the normalcy of male offending, in contrast to the abnormal or 'deviant' connotations associated with the female offender (INSERT FIGURE 11 HERE). 
Another example of this was evidenced in Figure 3 and Figure 7 (see below), where Carr appears in court via video link. (INSERT FIGURE 3 HERE)

The video link was used for Carr's first appearance in court, as there were fears for her safety whilst travelling to her trial, which was mostly due to the threat of harm which may have been caused by members of the public. However, this context is not evident in the two aforementioned images and rather all that is visibly clear is that Carr is present on a TV screen. In Figure 3 the angle of the male spectator, i.e. standing close to the TV screen, slightly open mouthed, reinforces the voyeuristic nature of the image. In addition, because the spectator is looking inwardly towards the TV screen, the viewer of the court drawing is also indirectly invited to participate in the viewing of the 'spectacle’.

It is significant to note that this notion of the 'spectacle' is not unique to women offenders in court drawings, as evidenced by Figure 9 as Huntley is the subject of the courtroom gaze, with Carr also joining in on the spectatorship. However, here Huntley is actively speaking, giving his testimony in the dock, thus the attention of the spectator is unsurprising. Yet the court drawings of Carr, particularly those of the videolink, collectively emphasise the 'spectacle’ of her being trial, her passivity, due to her not actively speaking, as well as her status as 'other' within the male space of the courtroom, due to her not being physically present at this point of the trial. 
In Figure 4 Vanessa George is the central figure and the crowds of spectators in the background are looking towards her from behind. (INSERT FIGURE 4 HERE).

Nead (2005) argues that in court drawings, "identities slip in and out of focus; faces resemble people we know, or feel we should know, but features dissolve and are forgotten” (Nead, 2005: 181). This is particularly relevant here, as the active judgement of the spectators in Figure 4 contradicts the usual passivity of spectators in court drawings (Nead, 2005; Mulcahy, 2015). Denotatively, this image highlights the high numbers of spectators present during the trial. However connotatively (Barthes, 1977), whilst the identity of the spectators lacks specificity, the outward expression of emotion, coupled with the collective, united grouping behind George, visually reinforces her status as 'other' and emphasises the incomprehensibly of the female child sex offender. Furthermore, there were no similar court drawings of her male co-defendant, Colin Blanchard and significantly all images of him did not have any spectators. This suggests that whilst George's role in the offending required the collective outrage of the spectator to emphasise her deviancy, Blanchard's role did not visually require the same level of distain or disgust. This reinforces the existing connotations and discourses surrounding female child sex offenders, such as beast and monster (Hayes and Baker, 2014; Gavin, 2009), whilst demonstrating the lack of available or nuanced explanations for such offending.

Collectively, the monstrous connotations and voyeuristic nature of the aforementioned court drawings collectively serve to represent the women as 'other' and thus 
‘essentially' and 'morally' different to 'normal' members of society (Young, 1999). Each of the women were positioned as a spectacle to observe and survey in each of the aforementioned drawings, particularly due to the location of the women in the image (i.e. in a glass box, at the centre or via video link) and the angles of those present in the drawing. Significantly, the women's male co-defendants were not drawn in a way that emphasised the 'spectacle' of them being on trial (with the exception of figure 9) and rather Figures 2, 9 and 10 in particular reinforce their status as active members of the courtroom as opposed to 'others'. Furthermore, the construction of the images arguably provides a visual example of Mathisen's (1997) concept of the synoptican. This concept forms the opposite process of Foucault's panoptican, developed by Bentham (1995), and outlines a process of modern surveillance whereby the 'many watch the few'. The 'many' can be defined in two ways here. Firstly, as those who were drawn as being present in court. Due to the majority of this 'many' being men according to the court artist's interpretation, this serves to emphasise the gendered nature of this synoptic process in court. Secondly, the 'many' could also be defined as those who view the court drawings. The 'spectacle' of the drawings offers an indirect invitation for the public to observe the female co-offenders in the ordinarily invisible space of the courtroom, thus highlighting the potential ideological influence of court drawings.

\section{Mad and/ or bad? - An analysis of the women's facial expressions}


The women's facial expressions are arguably one of the most significant aspects of the court drawings, as they are able to suggest or imply how they felt about their role in the offending, or at least how this was interpreted by the court artist. This is particularly significant when considering how the court drawings may represent the cultural and social processes that underpin the construction of women criminals in court.

Many of the court drawings analysed suggest a distinct lack of remorse or emotion displayed by each of the women and this was particularly the case for Vanessa George. In the three court drawings analysed of George, she appeared to be impassive and her facial expression insinuated a distinct lack of regret. In Figure 5 the juxtaposition of Angela Allen’s (George’s co-offender) clear display of emotion with Vanessa George’s inexpressive stare reinforces George’s emotionless state. (INSERT FIGURE 5 HERE).

This is further emphasised as the sketch of Colin Blanchard (George's co-offender) demonstrates a basic level of emotion, due to the slightly furrowed brow. The contrast in the three offender's expressions implies that George was indifferent and failed to demonstrate remorse for her role in the offending in court. Furthermore, in Figure 2 George's lack of emotion is particularly prominent when juxtaposed with the emotional reactions of those who witnessed the trial behind her, particularly the man breaking down in tears. Barthes (1977) argues that images are loaded messages packed with encoded cultural meanings that are not apparent at first glance. With this in mind, 
George’s visual lack of remorse connotatively reinforces her lack of femininity and failure to adhere to the idealistic image of womanhood (Naylor, 2001), thus complimenting wider discourses associated with the female child sex offender (Hayes and Carpenter, 2013).

Furthermore, in Figure 6 Carr also displays a distinct lack of feeling or reaction. (INSERT FIGURE 6).

The profile angle of Carr's face, combined with her lack of expression infers that she is aloof and indifferent to her offending, which consequently implies a lack of remorse. Women offenders are usually viewed to be both child-like and emotional (such as in the work of Lombroso and Ferrero) or mean and emotionless. The constructions of George and Carr in the aforementioned images represent them as women who are unable or unwilling to demonstrate emotion, thus reinforcing their deviation from ideal womanhood and femininity. However, such explanations rely on deterministic assumptions about women's biology and psychology, which arguably has far-reaching implications for deviant and non-deviant women alike (Jewkes, 2015).

However, Figure 7 portrays a very different side to Carr's personality and suggests that she did demonstrate some level of emotion when she appeared in court via video link. (INSERT FIGURE 7 HERE).

This drawing constructs Carr as being visibly gaunt, frail and drained, with tired eyes, protruding cheekbones and slumped shoulders. In stark contrast to the previously 
analysed drawing of Carr, this image implies that she was physically and emotionally affected by her appearance in court, thus suggesting that in many ways, she adhered to the dominant expectation that female offenders should visibly demonstrate regret and emotion (Lloyd, 1995). However, of particular significance to this drawing is the prominent and bold image of cartoon character, Daffy Duck, on her jumper, also seen in Figure 4 Although it is appropriate that this was included, as she was wearing this item of clothing for her video appearance in court, the court artist's bold use of colour and defined outline employs a higher modality for this aspect of the image, thus enhancing its perceived significance and relevancy to the overall visual construction of Carr. The wider context of the image production (Pink, 2007) is particularly significant here, as Daffy Duck is a crazed and unpredictable cartoon character and thus by exaggerating this aspect of the image, it arguably implicitly locates Carr as a 'crazy' and 'mad' woman.

Nineteenth century thinkers, such as Lombroso and Freud, have been profoundly influential in constructing notions of female pathology as an explanation for women's offending and the casualness with which women's crimes are medicalised is well documented (Jewkes, 2015; Morrisey, 2003; Wilczynski \& Sinclair, 1999). As highlighted by Jewkes (2015: 149), criminal justice representatives and society find it much easier to "accept that a woman has committed violent or heinous offences if she can be categorised as a deluded lunatic or unstable hysteric”. 
The previous discussion highlights that Maxine Carr's facial expressions and general demeanour differed, depending on the stage of the trial, as she appears to move from being frail to femme fatale within a short space of time. Whilst previous research emphasises the dichotomous nature of the mad/ bad narrative (Lloyd, 1995), this analysis suggests that the either/ or nature of this binary is not reflected in the visual analysis of Carr, as she was both mad and bad, dependent on the day/ stage of the trial, with her suggested 'madness' decreasing as the trial progressed. The agency of Carr should be recognised here, as this change in character may have reflected her overall demeanour in court. However, this also highlights the significance of utilising Pink's (2007) approach to visual analysis here, as Carr’s differential visual construction emphasises the impossibility of gaining a true visual account of any process and also demonstrates the significance of the context of image production. Carr's changing visual representation in the aforementioned court drawings emphasises the subjective nature of court drawings and the ways in which the end result can be influenced by the court artist's interpretation of the trial and female offenders themselves.

Furthermore, whilst Carr's visual construction changed from 'mad' to 'bad', Huntley’s facial expressions remained consistent, displaying low levels of emotion throughout the trial (see Figures 9, 10 and 12) INSERT FIGURE 12 HERE This suggests that whilst Huntley was visually constructed as being in control of his emotions, even when in the dock, the changeability of Carr's emotions implies a lack of control and irrationality. As highlighted by Russet (1989: 42), “if men characteristically 
thought, women characteristically felt”. Women have historically been defined by their nature, yet men continue to be defined as 'rational and cultured' beings and such constructions are particularly evident in typically 'male spaces', such as the courtroom (Sydie, 1987). The contrasting constructions of Carr and Huntley's facial expressions in the court drawings analysed reveal the fragility of the law's relationship with the feminine, in which realms of emotion contradict the laws masculine domain of control, discipline and sobriety (Mulcahy, 2015)

In Figure 7 and Figure 8 Pryce's general presentation arguably reinforces what was already known about her at this stage of the trial, namely that she was a successful economist and thus an intelligent woman. (INSERT FIGURE 7 HERE).

Her intelligence is particularly reinforced by her facial expression in the aforementioned images, emphasised by the hand on the chin, indicative of the well-known image of a 'thinking' pose, which consequently represents her as a woman who is in control and able to understand and consider the legal context of the trial. (INSERT FIGURE 8 HERE).

However, from my experience of being in court, Pryce was conversely rather nervous in the dock, which contradicts the confident figure reflected in the drawings. This suggests that the drawings may have been influenced by the court artist's subjectivities and personal interpretation of Vicky Pryce, as well as her understanding of female offending more generally (Cheston, 2010; Pink, 2007). 
The representation of Pryce in these drawings is particularly interesting when considered within the context of her cited defence of marital coercion. The defence is provided by section 47 of the Criminal Justice Act 1925 and is based on the premise that a wife is not responsible for a crime if pressured (physically or morally) to commit it by her husband. To cite this defence, the wife must have committed the offence both in the presence and under the coercion of her husband (McDowell, 2013). Pryce’s intelligent and musing expressions arguably portray her as a woman who was unlikely or potentially unable to be coerced or controlled, thus contradicting her defence and overall perspective. Thus when this drawing is considered within the wider context of Pryce's case, it indirectly indicates her deviousness and ability to manipulate, due to her outward appearance contradicting her written/ verbal defence. Manipulation and deviousness are typical elements of an essentialist discourse used to define and describe female offenders (Pollak, 1950) and in spite of various feminist scholars reinterpreting the ways in which such dominant discourses are constituted (Smart, 1977; Klein, 1973; Heidensohn, 1996), such narratives are still influential today when considering the representation of female offenders.

\section{Bringing together the intersection of gender, court drawings and visual criminology}


This paper argues that despite representing the 'objective’ context of the courtroom, court drawings are not value-free images, which is in part influenced by the subjectivity of the court artist. While the subjective influence of the photographer has been increasingly acknowledged (Finn, 2009; Sekula, 1981), the photograph is able to capture a more objective version of a 'moment in time' in comparison to drawings or sketches. Court drawings represent a partial image of what goes on in court and often a whole day of a trial is encapsulated in one drawing. This is particularly evident when comparing the construction of Carr in Figure 7 to her other court drawings. They collectively offer contradictory images of the 'type' of woman that she was visually represented to be in court. Whilst MC Image 3 represents her as a 'mad' woman, the others mostly construct her as a detached, femme fatale. This not only evidences the subjective and partial nature of court drawings, but also highlights that the overly simplistic tried and tested narratives of female offenders, which are often utilised in popular mediated representations, also permeate court artistry. This highlights the crude and limited options that are available to represent female offenders, which demonstrates the need to develop more sophisticated and nuanced alternatives (Comack \& Brickey, 2007)

Court drawings are produced in a time-pressured environment from memory and are often intended for media use and thus a public audience. This therefore highlights that the interconnected, reciprocal relationship between media and legal systems (Surette, 1998) also influences the production and use of court drawings. Furthermore, as well as 
the potential influence of the intended audience, the court artist's own belief systems are likely to influence their interpretation of the day in court and subsequently their sketches, highlighting the importance of considering how visual content is informed by subjectivities (Pink, 2007).

As previously discussed, there are only three court artists in the UK at the time of writing, all of whom are women. The simplistic and often dichotomous ways in which the women were visually constructed in each of the court drawings analysed in this paper, suggests that dominant explanations of female offending and prevailing social constructions of gender more broadly, particularly within law, may have influenced the court artist's interpretations, thus highlighting the power of such discourses. However, it is acknowledged here that in the absence of speaking with the court artists, authentic conclusions are unable to be drawn about their standpoint with respect to their subjects. In addition, the comparisons with the visual construction of the women's male codefendants highlights the ways in which gendered discourses and myths may influence court artist's drawings of female co-offenders in particular. Court drawings are the primary way in which the public are able to 'see' what happens in court, therefore the partial, simplistic and often biased representation of the trial evidenced in the drawings analysed in this paper may influence public understanding of the trial process and the women themselves. This is particularly significant when considered within the context of the cultural, social and political power of images of crime and deviancy (Rafter, 2014; Ferrell et al, 2008; Hayward \& Presdee, 2010; Carrabine, 2014). 
Furthermore, similarly to the photograph, it is argued in this paper that the power of court drawings lie in their ability to display an event, which is currently hidden from public view, and on their connotative ability to draw upon symbolic systems, visually representing ideological codes of meaning (Barthes, 1977). It is arguably the secrecy of the courtroom, which has enabled court drawings to maintain their level of authority as a form of knowledge and insight.

Although each of the drawings were initially analysed individually, the findings highlight that there are clear similarities between the ways in which the women were visually represented in each of the images. The drawings emphasised the courtroom as being a 'male space', whereby women, by their very nature, are other and thus visually excluded as being active participants. In addition, the drawings collectively relied on dominant, restrictive and gendered constructions of female offenders, such as being 'other', mad, emotionless and lacking remorse (Jewkes, 2015). Furthermore, the gendered constructions in the drawings of the female offenders were not evident in the drawings of their male counterparts, thus highlighting the ways in which gender-related myths and stereotypes also permeate court artistry. This collectively suggests that the familiar dichotomous categorisations and typologies often applied to female offenders, as identified by critical media scholars (For example, Berrington \& Honkatukia, 2002; Jewkes, 2015; Barnett, 2006), are also utilised by court artists. Female offenders are often pathologised and defined by deterministic explanations such as being inherently evil, 'unhinged’ or emotionless (Myers and Wight, 1996; Lavie-Dinur, Karniel, Azran, 
2013; Naylor, 2001; Barnett, 2006). Whilst such constructions are more directly evident in media discourse, the less obvious techniques used by court artists, such as the use of passive or musing facial expressions, and contrasting emotions to others in the sketch, produced similarly dichotomous and gendered results. With this in mind, the court drawings analysed suggest that simplistic understandings of female offending continue to influence dominant discourses and explanations of such criminality, which translate to visual as well as written representations.

\section{Conclusion}

Overall, the court drawings analysed in this paper arguably reflect the cultural and social processes that underpin the public understanding of female offenders in court. The dichotomous and gendered drawings of the women reflect a partial and one-sided ‘version' of their actual experiences in court, which consequently fail to encapsulate or account for the women's perspective or lived experiences. Although it is recognised that a drawing is only able to capture a limited and subjective version of the day in court, the reliance on familiar gendered motifs, the emphasis on the male environment of the courtroom and the fact that none of the women are speaking in the drawings implies that women are 'other' in court and thus denied the opportunity to be seen as agents of their own narrative (Ballinger, 2012). Although audience effects cannot be determined within 
this paper, the symbolic power of images of crime and criminal justice (Hayward and Presdee, 2010) and the invisibility and mystery surrounding the trial process in England and Wales suggests that court drawings may impact upon the ways in which the public perceives and understands women in court. Feminist theorists have noted that the law holds a symbolic superiority in the production of knowledge and truth (Inglis, 2003) and is constructed according to male values (Ballinger, 2012). This paper therefore concludes that similarly to women's experiences of court more broadly (Ballinger; 2012; Carline, 2005; Naffine, 1996), court drawings limit women offenders to oversimplistic dichotomies and discourses, which are beset with myths and prejudices. This suggests that the visual representation of the court drawing serves to reinforce dominant and gendered discourses, which characterise women's experiences of the courtroom.

Finally, visual culture has played a critical role in the construction and constant reconstruction of legal norms. Although there is now a considerable body of work which looks at law in popular culture, the relevance of still images and court artistry continues to be neglected (Mulcahy, 2015). It is argued here that criminologists and social-legal scholars should move beyond the text to a broader interrogation of what art and the image can tell us about law, thus expanding the criminological imagination.

\section{References}


Aradau, Claudia. Hill, Andrew. 2013. The Politics of Drawing: Children, Evidence and the Darfur Conflict, International Political Sociology, 7, pp. 368-387

Andreou, Eleni. \& Bonoti, Fotini. 2010. Children’s bullying experiences expressed through drawings and self-reports, School Psychology International, 31, pp. 64-177 Austin, Joe. 2001. Taking the Train: How Graffiti Art Became an Urban Crisis in New York City. New York: Columbia University Press

Ballinger, Anette. 2000 Dead Woman Walking. Aldershot: Ashgate.

Ballinger, Anette. 2007. Masculinity in the Dock: Legal Responses to Male Violence and Female Retaliation in England and Wales, 1990-1965, Social and Legal Studies, 16, pp. 459-481

Ballinger, Anette. 2012 A Muted Voice from the Past: The 'Silent Silencing' of Ruth Ellis. Social and Legal Studies, 21, pp. 445-467

Barlow, Charlotte. 2015. Silencing the other: Gendered Representations of Co-accused Women Offenders. Howard Journal of Criminal Justice. DOI: 10.1111/hojo.12145

Barnett, Barbara. 2006 Medea in the Media: Narrative and Myth in Newspaper Coverage of Women who Kill their Children. Journalism, 7, pp. 411-432.

Barthes, Roland. 1977. Image-music-text. London: Fontana Press 
Beard, Mary. 2014. The Public Voice of Women. London Review of Books, 36, pp. 1114

Bentham, Jeremy. 1995. The Panopticon writings. London: Verso.

Berrington, E. \& Honkatukia, P. 2002. An Evil Monster and a Poor Thing: Female

Violence in the Media. Journal of Scandinavian Studies in Criminology and Crime

Prevention, 3, pp. 50-72.

Birch, Helen 1993. 'If Looks could Kill: Myra Hindley and the Iconography of Evil', in Moving Targets: Women, murder and representation. Virago Press: London

Bondi, Liz. 1997. In Whose Words? On Gender Identities, Knowledge and Writing Practices. Transactions of the Institute of British Geographers. 22, pp. 245-258

Brown, Michelle. \& Rafter, Nicole. 2013. Genocide Films, Public Criminology,

Collective Memory. British Journal of Criminology, 53, pp. 1017-1032.

Carlen, Pat. 2002. Women and Punishment: The Struggle for Justice. Cullompton: Willan

Carline Anna. 2005 Women who Kill their Abusive Partners: From Sameness to Gender Construction. Liverpool Law Review, 26, pp. 13-44.

Carrabine, Eamon. 2012. Just Images: Aesthetics, Ethics and Visual Criminology. British Journal of Criminology. 52, pp. 463-489. 
Carrabine, Eamon. 2014. Seeing things: Violence, voyeurism and the camera. Theoretical Criminology, 18, pp. 134-158

Cheston, Paul. 2010. Court Scenes: The Court Art of Priscilla Coleman. London: Wildy, Simmonds and Hill.

Coleman, Patricia. 2003. Figure 6, Court Drawing. Last viewed 10/10/2015, http://www.priscilla-coleman.co.uk/gallery/searchLocation.php?sel_location=40 Coleman, Patricia. 2003. Figure 7 Court Drawing. Last viewed 10/10/2015, http://www.priscilla-coleman.co.uk/gallery/searchLocation.php?sel_location=40 Coleman, Patricia. 2003. Figure 9, Court Drawing. Last viewed 10/10/2015, http://www.priscilla-coleman.co.uk/gallery/searchLocation.php?sel_location=40 Coleman, Patricia. 2003. Figure 10, Court Drawing. Last viewed 10/06/2015, http://www.priscillacoleman.co.uk/gallery/searchLocation.php?sel_location=40

Coleman, Patricia. 2003. Figure 12, Court Drawing. Last viewed 10/06/2015http://www.priscillacoleman.co.uk/gallery/searchLocation.php?sel_location $\underline{=40}$

Colemn, Patricia. 2013. Figure 1, Court Drawing. Last viewed 10/10/2015, http://www.thetimes.co.uk/tto/news/uk/crime/article3693891.ece 
Coleman, Patricia. 2013. Figure 2, Court Drawing. Last viewed 10/10/2015, http://www.itv.com/news/story/2013-02-04/chris-huhne-and-ex-wife-vicky-pryce-tostand-trial-over-claims-she-took-speeding-points-for-him/

Coleman, Patricia. 2013. Figure 7, Court Drawing. Last viewed 10/10/2015, http://www.dailymail.co.uk/news/article-2274103/Chris-Huhne-s-scorned-wife-VickyPryce-called-lover-man-hatched-plot-destroy-him.html

Coleman, Patricia. 2013. Figure 8, Court Drawing. Last viewed 10/10/2015, http://www.itv.com/news/2013-03-07/chris-huhnes-ex-wife-found-guilty-over-takingpoints/

Comack, Elizabeth \& Brickey, Salena. 2007. Constituting the Violence of Criminalized Women. Canadian Journal of Criminology and Criminal Justice, pp. 1-36.

Cook, Elizabeth. 2009. Figure 4, Court Drawing. Last viewed 10/06/2015, http://www.mirror.co.uk/news/uk-news/as-tv-trials-threaten-to-kill-off-courtroom840903

Cook, Elizabeth. 2009. Figure 5, Court Drawing. Last viewed 10/06/2015, http://www.dailymail.co.uk/news/article-1217415/Nursery-worker-Vanessa-Georgeinternet-accomplices-plead-guilty-sexually-assaulting-young-children.html 
Cunneen, Chris. 2010. Framing the Crimes of Colonialism: Critical Images of Aboriginal Art. In K, Hayward \& M. Presdee (Eds). Framing Crime: Cultural Criminology and the Image. London: Routledge.

Edwards, Susan 1984. Women on Trial: A Study of the Female Suspect, Defendant and Offender in the Criminal Law and Criminal Justice System. Manchester: Manchester University Press.

Ferrell, Jeff., Hayward, Keith., Morrison, Wayne., \& Presdee, Mike. 2004. Cultural Criminology Unleashed. London: Glasshouse Press.

Ferrell, Jeff., Hayward, Keith \& Young, Jock. 2008. Cultural Criminology: An Invitation. London: Sage.

Ferrell, Jeff. \& Cecille de Voorde, C. 2010. The Decisive Moment: Documentary Photography and Cultural Criminology. In Hayward, Keith. and Presdee, Mike. (eds), Framing Crime. London: Routledge-Glasshouse.

Finn, John. 2009. Capturing the Criminal Image: From Mug Shot to Surveillance Society. Minnesota: University of Minnesota Press

French, S. 1996. Partners in crime. In Myers, A. \& Wight, S. (eds). No angels: Women who commit Violence. London: Pandora 
Garland Thomson, Rose. 1997. Disability, Identity and Representation: An Introduction. In, Extraordinary Bodies: Figuring Physical Disability in America Culture and Literature. New York: Columbia University Press. Pp 5-15.

Gavin, Helen. 2009. “Mummy wouldn't do that” the Perception and Construction of the Female Child Sex Abuser. In: Evil, Women and the Feminine, 1-3 May 2009, Budapest, Hungary.

Glazer, Nathan. 1979. On Subway Graffiti in New York. The Public Interest, 54, pp. 3 11.

Grabe, Marie, Trager, Elizabeth, Lear, Melissa and Rauch, Jennifer 2006. Gender in Crime News: A Case Study Test of the Chivalry Hypothesis, Mass Communication and Society, 9, pp. 137-163

Greer, Chris. 2007. Newsmedia, Victims and Crime. In Davies, P.M., Francis, P. \& Greer, C. (eds) Victim, Crime and Society. London: Sage.

Hardin, Marie, \& Whiteside, Erin. 2010. Framing through a feminist lens. In Angelo, P.D. \& Kuypers, J. (Eds.), Doing News Framing Analysis (pp. 312-330). New York: Routledge.

Hayes, Sharon. \& Baker, Bethany. 2014. Female Sex Offenders and Pariah Femininities: Rewriting the Sexual Scripts. Journal of Criminology, p1-8 
Hayward, Keith. \& Presdee, Mike. 2010. Framing Crime: Cultural Criminology and the Image. London: Routledge.

Heidensohn, Francis. 1996 Women and Crime. $2^{\text {nd }}$ edition. Basingstoke: Macmillan Heidensohn, Francis. 2002. Gender and Crime, Maguire, M., Morgan, R. \& Reiner, R. (eds). The Oxford Handbook of Criminology. Oxford University Press.

Inglis, Tom 2003. Truth, Power and Lies. Dublin: University College Dublin Press. Jewkes, Yvonne. 2015. Media and Crime. $3^{\text {rd }}$ Edition. London: Sage Jones, Phill., \& Wardle, Claire. 2008 ‘No emotion, no sympathy’: The Visual Construction of Maxine Carr. Crime, Media and Culture, 4, pp. 53-71.

Katz, C. Barnetz, Z, Hershkowitz, I. 2014. The Effect of Drawing on Children’s Experiences of Investigations Following Alleged Child Abuse, Child abuse and neglect, 14, pp. $858-867$

Klein, Dorie. 1973. The Etiology of Female Crime: A Review of the Literature. Issues in Criminology, 8, pp.3- 30

Lavie- Dinur, Amit., Karniel, Yuval. \& Azran, Tal. 2013. 'Bad girls’: The use of Gendered Media Frames in the Israeli Media’s Coverage of Israeli Female Political Criminals, Journal of Gender Studies, 22, pp.1-21 
Lloyd, Ann 1995. Doubly Deviant, Doubly Damned: Society’s Treatment of Violent Women. Penguin group: London.

Lombroso, Cesare 2006/1876. Criminal Man. Translated and with a new introduction by Mary Gibson and Nicole Hahn Rafter. Durham, NC: Duke University Press.

Lombroso, Cesare \& Ferrero, Guglielmo. 2004/1893. Criminal Woman, the Prostitute, and the Normal Woman. Translated and with a new introduction by Nicole Hahn Rafter and Mary Gibson. Durham, NC: Duke University Press.

MacKinnon, Catherine. 1989. Toward a Feminist Theory of the State. Harvard: Harvard University Press.

Marder, Nancy 2013. The Court and the Visual: Images and Artifacts in US Supreme Court Opinions. Chicago-Kent Law Review, 88, pp. 331-364

Mathiesen, Thomas. 1997. The Viewer Society: Michel Foucault’s 'Panopticon’ Revisited. Theoretical Criminology, 1, pp. 215-234.

McDowell, Helen. 2013. Marital coercion: A rare and unusual defence, http://www.petersandpeters.com/blog/helen-mcdowell/marital-coercion-rare-andunusual-defence. Retrieved 26th October 2014.

Meyers, Marian. 1997. News coverage of Violence Against Women: Engenerdering blame. Newbury Park: Sage. 
Morrisey, Belinda 2003. When Women Kill: Questions of Agency and Subjectivity. London: Routledge

Mulcahy, Linda. 2015. Watching women: What Illustrations of Courtroom scenes tell us about Women in the Public Sphere in the $19^{\text {th }}$ Century. Journal of Law and Society, 42, pp. 53-73

Mulcahy, Linda. 2015b.Docile Suffragettes? Resistance to police photography and the possibility of object-subject transformation. Feminist legal studies, 23, pp79-99

Myers, Alice. \& Wight, Sarah. 1996 No Angels: Women who Commit Violence. London: Pandora

Naffine, Ngaire. 1987. Female Crime: The Construction of Women in Criminology. London: Allen Unwin

Naffine, Ngaire. 1996. Feminism and Criminology. Philadelphia: Temple University Press

Naylor, B. 2001. Reporting Violence in the British Print media: Gendered stories. The Howard Journal, 40, pp.180-194.

Nead, Linda. 2005. Courtroom sketching: Reflections on History, law and the Image. In Freeman, M. Law and Popular Culture. Oxford University Press 
Pink, Sarah 2007. Doing Visual Ethnography: Images, Media and Representation in Research. London: Sage

Pollak, Otto. 1950/1961. The Criminality of Women. New York: AS, Barnes/ Perpetua

Poole, Debra. \& Dickinson, Jason. 2014. Comfort Drawing During Investigative Interviews: Evidence of the Safety of a Popular Practice. Child Abuse and Neglect, 38, pp. 192-201

Quenzler, Julia. 2003. Figure 3, Court Drawing. Last viewed 10/10/2015, http://www.mirror.co.uk/news/uk-news/as-tv-trials-threaten-to-kill-off-courtroom840903

Quenzler, Julia. 2013. Figure 11, Court Drawing. Last viewed 10/10/2015, http://www.bbc.co.uk/news/uk-17053575

Rafter, Nicole. 2014. Introduction to Special Issues on Visual Culture and the Iconography of Crime and Punishment, Theoretical Criminology, 18, pp.127-133

Riggins, Stephen. Harold 1997. The Language and Politics of Exclusion. Sage:

Thousand Oaks, CA. p.1-30.

Rose, Gillian. 2007. Visual Methodologies: An Introduction to the Interpretation of Visual Materials. London: Sage 
Russett, Cynthia. 1989 Sexual Science: The Victorian Construction of womanhood. London: Harvard University Press.

Sekula, Allan. 1981. The Traffic in Photographs. Art Journal, 41, pp. 15-25.

Smart, Carol. 1977. Women, Crime and Criminology. London: Routledge.

Smart, Carol. 1989. Feminism and the power of law. London: Routledge.

Snyder, Gregory. 2009. Graffiti lives: Beyond the tag in New York’s Urban

Underground. New York University Press.

Surette, Ray. 1998. Media, Crime, and Criminal Justice: Images and Realities. Belmont, CA: Wadworth.

Sydie, Ruth 1987. Natural Women, Cultured Men: A Feminist Perspective on Sociological Theory. Milton Keynes: Open University Press.

Walklate, Sandra. Mythen, Gabe. McGarry, Ross. 2011. Witnessing Wooton Bassett: An Exploration in Cultural Victimology. Crime, Media, Culture. 7, pp. 149-165

Walklate, Sandra., McGarry, Ross. \& Mythen, Gabe. 2014. Trauma, Visual Victimology and the Poetics of Justice. In M. Haviid- Jacobsen. Poetics of Justice. London: Routledge. 
Wilczynski, A. \& Sinclair, K. 1999. Moral Tales: Representations of Child Abuse in the Quality and Tabloid Media, Australian and New Zealand Journal of Criminology, 32, pp.262-283

Wykes, Maggie 1998. A Family Affair: The British Press, Sex and the Wests, In C. Carter, G. Branston, S. Allen (eds). News, Gender and Power. London: Routledge. Yardley, Elizabeth. \& Wilson, David. 2015. Female Serial Killers in Social Context: Criminological institutionalism and the case of Mary Ann Cotton. Bristol: Policy Press Young, Alison. 2005. Judging the image: Art, Value and Law. London: Routledge Young, Jock. 1999 The Exclusive Society. London: Sage

Young, Jock. 2011. The Criminological Imagination. Polity Press: Cambridge. 